Vol. 6 (1997): 1-10.

\title{
Genetic parameters for growth traits in pigs estimated using third degree polynomial functions
}

Marja-Liisa Sevón-Aimonen

Department of Animal Science, P.O. Box 28, FIN-00014 University of Helsinki, Finland. Current address: Agricultural Research Centre of Finland, Institute of Animal Production, FIN-31600 Jokioinen, Finland.

e-mail: marja-liisa.sevon-aimonen@mtt.fi

Kristina Sternberg

Department of Animal Science, P.O. Box 28, FIN-00014 University of Helsinki, Finland. Current address: Finnish Animal Breeding Association, P.O. Box 40, FIN-01301 Vantaa, Finland.

Matti Ojala

Department of Animal Science, P.O. Box 28, FIN-00014 University of Helsinki, Finland

A total of 8745 purebred Yorkshire and Landrace pigs extracted from Finnish progeny test station data was analysed. The pigs were weighed weekly during the test. A third degree polynomial function, age $=\mathrm{f}$ (weight), was fitted separately for each pig and was used to describe the growth patterns of individual pigs.

Their live weight at the inflection point $\left(\mathrm{LW}_{\mathrm{ip}}\right)$ was $72 \mathrm{~kg}$, age at the inflection point $\left(\mathrm{AGE}_{\mathrm{ip}}\right) 126 \mathrm{~d}$, and maximum daily gain $\left(\mathrm{DG}_{\max }\right) 1111 \mathrm{~g} / \mathrm{d}$, on average. The average daily gain from 30 to $90 \mathrm{~kg}$ $\left(\mathrm{ADG}_{30-90}\right)$ was $957 \mathrm{~g} / \mathrm{d}$ and in the smaller weight ranges (30 to 50,50 to 70 and 70 to $90 \mathrm{~kg}$ ) the average daily gains were 829,1042 and $1046 \mathrm{~g} / \mathrm{d}$, respectively.

Genetic parameters for growth and carcass traits were estimated using REML with an animal model. The heritability estimates $\left(h^{2}\right)$ for $\mathrm{LW}_{\text {ip }}, \mathrm{AGE}_{\mathrm{ip}}$ and $\mathrm{ADG}_{30-90}$ were $0.08,0.33$ and 0.23 , respectively, and for smaller weight ranges from 0.14 to 0.21 . Fast growing and lean animals had higher $\mathrm{LW}_{\text {ip }}$ than others and the $\mathrm{r}_{\mathrm{g}}$ between $\mathrm{LW}_{\text {ip }}$ and $\mathrm{ADG}_{30-90}, \mathrm{DG}_{\max }$ and $\mathrm{M} \%$ was $0.58,0.73$ and 0.57 , respectively. The $\mathrm{r}_{\mathrm{g}}$ between $\mathrm{ADG}_{30-90}$ and $\mathrm{M} \%$ was close to zero.

Key words: growth curve, growth patterns, daily gain, carcass composition, heritability, genetic correlations

\section{Introduction}

Growth performance of slaughter pigs is among the most fundamental factors determining the profitability of pig production. It is therefore important to understand the growth process as fully as possible. Growth is usually considered as the rate of growth during a defined growing period. This rate gives information about the

(C) Agricultural and Food Science in Finland

Manuscript received May 1996 


\section{AGRICULTURAL AND FOOD SCIENCE IN FINLAND}

Sevón-Aimonen, M.-L. et al. Genetic parameters for growth traits in pigs

average level of growth performance but not about changes in in rate during the growing period. To be able to examine these changes, we need growth curves for individual pigs.

The mathematical functions most often used to describe and predict growth are the Richards function (Richards 1959) and its special cases (e.g. logistic, Gompertz (Laird 1966)) and polynomial functions. The main reason for the popularity of the Richards function and its special cases is the good biological interpretability of parameters. However, with these functions, observations are needed on a wide age and weight range of growth, otherwise the risk of false results is increased. In pigs, the weighing data are usually only from a short period, from about $25 \mathrm{~kg}$ to $100 \mathrm{~kg}$ live weight. Such short periods of growth can be described accurately with polynomial functions (Kanis 1988). The degree of the polynomial function determines how many inflection points can exist in the curve. With a polynomial of the third degree, there can be one inflection point in the curve, and the maximum daily gain can be estimated. A polynomial of the fifth degree or higher would permit the detection of multiphasic growth curves, as suggested by Koops and Grossmann (1991). However, when weighing records are available for only a short period or the number of observations is insufficient, polynomials of a high degree might just picture random environmental fluctuations in growth.

Live weight growth is that it is traditionally viewed as a continuous process that results in a single, smooth, S-shaped growth curve with an inflection point at about $30 \%$ of the mature weight (Brody 1945). Environment obviously causes some alteration in growth patterns. Whittemore (1986, 1987), for example, argued that the shape of the growth curve depends on animal management and feeding practices more than on any biological age or weight-related rule. Studies of Vangen (1977), Cöp and Buiting (1977) and Krieter (1986) have, however, indicated that there is also genetic variation in changes in growth traits during the growing period. The growth curve is usually presented as a func- tion, $y=f(x)$, where $x$ is time and $y$ is size (Walstra 1980). In some cases, weight has been chosen to be x-variable (e.g. Kanis 1988, Schmidt 1991). Functionally growth processes seem to be associated with body weight more than with age (Kanis 1988, Timon and Eisen 1970).

The purpose of our study was to describe the shape of the growth curve and the factors affecting the growth pattern in Finnish test station pigs. We also sought to estimate heritabilities for and correlations among traits describing the growth pattern, growth rate and carcass composition.

\section{Material and Methods}

\section{Data and test procedure}

The data were obtained from the Finnish Animal Breeding Association and included weighing records and carcass measurements of all Yorkshire and Landrace pigs that arrived at test stations between August 1990 and July 1992. There was a total of 8745 animals with complete records in the data set. The proportions of the two breeds and sexes (castrated males and gilts) were about equal. The pigs were raised in groups of four fullsibs and were weighed weekly. They were hand-fed twice a day, according to a scale based on the mean weight of the fullsib group (Table 1). The feed mixture contained $1.0 \mathrm{FU} / \mathrm{kg}$ $(\mathrm{FU}=$ feed unit, $0.7 \mathrm{~kg}$ starch equivalent; Salo et al. 1990), 15\% digestible crude protein and $0.96 \%$ lysine. The average growing period was from 23 to $97 \mathrm{~kg}$ live weight, and the age of the pigs was 71 days at arrival and 152 days at slaughter.

\section{Fitting and classification of polynomial functions}

A polynomial of the third degree was chosen because it enabled us to obtain the position of the inflection point of the curve and estimate the 
Vol. 6 (1997): 1-10.

Table 1. Feeding scale according to live weight used in the pig test stations.

\begin{tabular}{ll}
\hline $\begin{array}{l}\text { Mean weight of } \\
\text { a fullsib group }\end{array}$ & $\begin{array}{l}\text { Kg feed per } \\
\text { pig per day }\end{array}$ \\
\hline $17.0-18.9$ & 1.000 \\
$19.0-19.9$ & 1.100 \\
$20.0-22.4$ & 1.200 \\
$22.5-24.9$ & 1.300 \\
$25.0-27.4$ & 1.400 \\
$27.5-29.9$ & 1.500 \\
$30.0-32.4$ & 1.600 \\
$32.5-34.9$ & 1.750 \\
$35.0-37.4$ & 1.850 \\
$37.5-39.9$ & 1.950 \\
$40.0-42.4$ & 2.050 \\
$42.5-44.9$ & 2.150 \\
$45.0-47.4$ & 2.250 \\
$47.5-49.9$ & 2.350 \\
$50.0-54.9$ & 2.450 \\
$55.0-59.9$ & 2.600 \\
$60.0-64.9$ & 2.700 \\
$65.0-69.9$ & 2.800 \\
$70.0-74.9$ & 2.900 \\
$75.0-79.9$ & 2.950 \\
$80.0-84.9$ & 3.050 \\
$85.0-94.9$ & 3.100 \\
$\geq 95.0$ & 3.200 \\
\hline
\end{tabular}

maximum daily gain. Age was chosen as the $y$ variable and weight as the $x$-variable because the growth of pigs is normally considered within a weight rather than an age range. The function, $y=f(x)$, was fitted individually to each animal's longitudinal age-weight data:

$y_{i j}=b_{i 0}+b_{i 1} x_{i j}+b_{i 2} x_{i j}{ }^{2}+b_{i 3} x_{i j}{ }^{3}+e_{i j}$

where $y_{i j}$ is the observation of age of the $i^{\text {th }}$ pig at the $\mathrm{j}^{\mathrm{jt}}$ weighing time, $(\mathrm{j}=1, \ldots, \mathrm{k}, \mathrm{k}=12$ on an average for a pig), $x_{i j}$ is the weight of the $i^{\text {th }}$ pig at the $\mathrm{j}^{\text {th }}$ weighing time, $\mathrm{b}_{\mathrm{i} 0}, \mathrm{~b}_{\mathrm{i} 1}, \mathrm{~b}_{\mathrm{i} 2}$ and $\mathrm{b}_{\mathrm{i} 3}$ are polynomial regression coefficients for the weight of the $i^{\text {th }}$ pig and $e_{i j}$ is a residual term. Fitting resulted in a polynomial function

$y_{i}=b_{i 0}+b_{i 1} x_{i}+b_{i 2} x_{i}^{2}+b_{i 3} x_{i}^{3}$

(function 1)

for every pig, which was the least squares approximation of the observed data.
The fitted curves were classified according to the combinations of the signs of the coefficients from the polynomial regression (function 1).

\section{Traits}

The eight traits studied were: live weight at the point of inflection ( $\left.\mathrm{LW}_{\mathrm{ip}}, \mathrm{kg}\right)$, age at the point of inflection $\left(\mathrm{AGE}_{\mathrm{ip}}, \mathrm{d}\right)$, daily gain at the point of inflection ( $D G_{\max }, \mathrm{g} / \mathrm{d}$ ), average daily gains from 30 to 50,50 to 70,70 to 90 and 30 to $90 \mathrm{~kg}$ live weight $\left(\mathrm{ADG}_{\text {weightl-weight2 }}, \mathrm{g} / \mathrm{d}\right)$ and percentage of lean meat with bone in high value cuts (back, shoulder, loin and ham) in carcass with head (M\%, \%).

The $\mathrm{LW}_{\text {ip }}$ of individual pigs was obtained by equating the second derivative of the fitted function 1 to zero. $\mathrm{AGE}_{\text {ip }}$ was obtained by placing $\mathrm{LW}_{\text {ip }}$ into function $1 . \mathrm{DG}_{\max }$ was estimated by placing $\mathrm{LW}_{\text {ip }}$ into the first derivate of function 1 , which results in $\mathrm{d}($ age $) / \mathrm{d}$ (weight) at the given weight; the corresponding estimate of daily gain was obtained by taking the inverse of it. The average daily gains in the given weight range were estimated by calculating age at the lower and upper weight limits using function 1 and dividing the weight difference by the age difference. For the figures, daily gain values at given weights (Figs 1,2) were obtained as $\mathrm{DG}_{\max }$

When daily gains and inflection point parameters were examined, only those animals having an inflection point within their real weighing period were included in the data. A total of 7419 animals fulfilled this condition.

\section{Statistical methods}

The data were analysed by the restricted maximum likelihood (REML) method (Patterson and Thompson 1971). The statistical analyses were made using PEST software package (Groeneveld 1990), which includes a variance component estimation program (Groeneveld 1993), based on the derivate-free procedure. Heritabilities were 
Sevón-Aimonen, M.-L. et al. Genetic parameters for growth traits in pigs

Fig. 1. Average trend of daily gain curves of pigs in curve types 1-6 presented in Table 2 . Daily gains at given weights were estimated using first derivative of third degree polynomials fitted to ageweight data of each pig (for details see section Material and methods).

Fig. 2. Daily gain curves in castrates and gilts. Daily gains at given weights were estimated using first derivative of third degree polynomials fitted to age-weight data of each pig (for more details see section Material and methods).
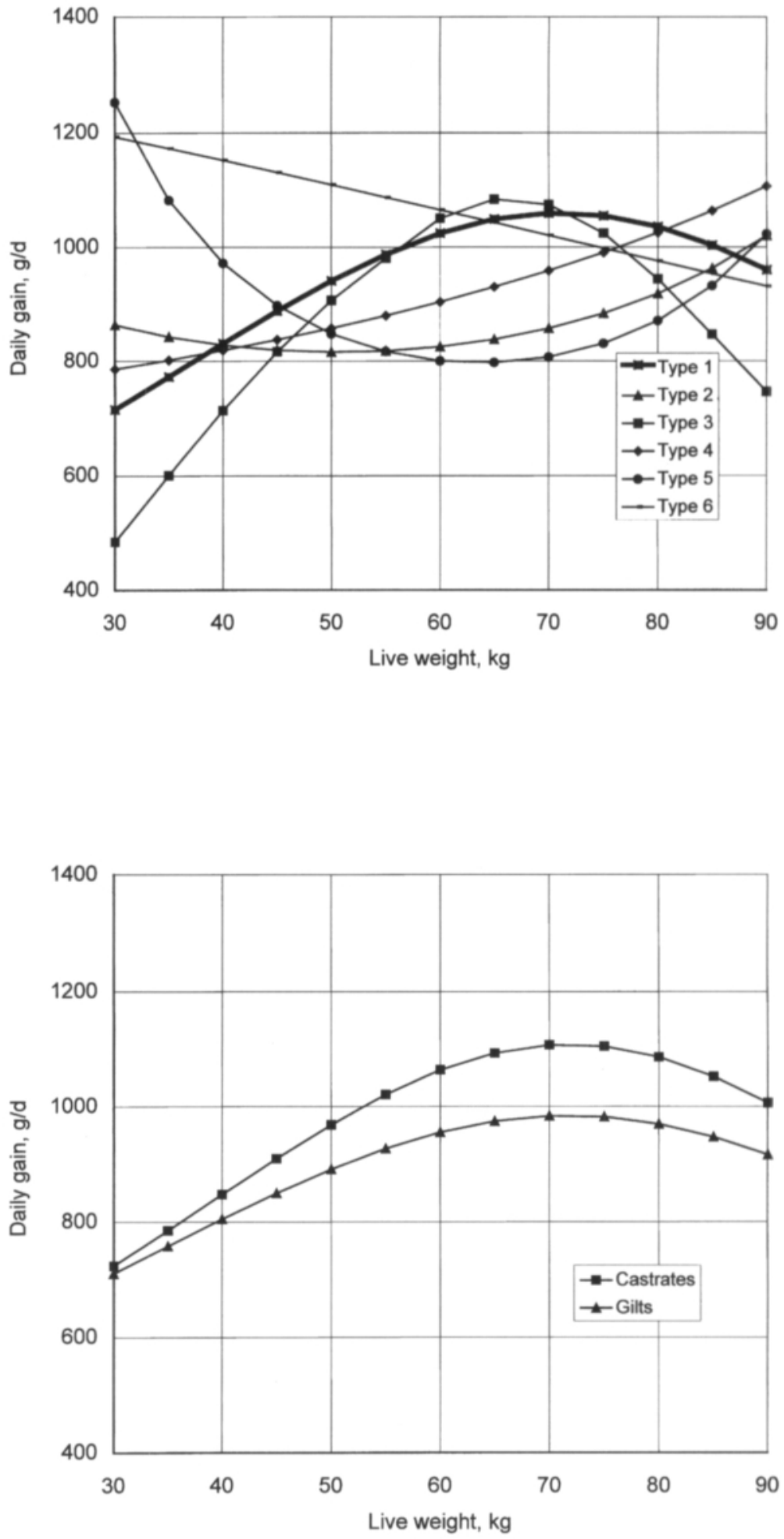
Vol. 6 (1997): 1-10.

estimated using a univariate model; genetic and phenotypic correlations using a bivariate model.

The model assumed was:

$y_{i j k l m n o}=\mu+b_{i}+s b_{j}+s_{k}+s_{1}+f_{m}+a_{n}+\varepsilon_{i j k l m n o}$

where

$\mathbf{y}_{\text {ijklmno }}=$ an observation

$\mu=$ population average

$\mathrm{br}_{\mathrm{i}}=$ fixed effect of the $\mathrm{i}^{\text {th }}$ breed (Yorkshire, Landrace)

$s b_{j}=$ fixed effect of the $j^{\text {th }}$ test station-batch subclass $(j=1, \ldots, 114)$

$\mathbf{s x}_{\mathrm{k}}=$ fixed effect of the $\mathrm{k}^{\text {th }} \operatorname{sex}$ (castrates, gilts)

$\mathrm{sr}_{1}=$ fixed effect of the $\mathrm{I}^{\text {th }}$ ratio of sexes in the group $(1=1, \ldots, 5)$

$\mathrm{fg}_{\mathrm{m}}=$ random effect of the $\mathrm{m}^{\text {th }}$ litter/fullsib group with expected value zero and variance $\sigma_{\mathrm{fg}}{ }^{2}$

$a_{n}=$ additive genetic effect of the $n^{\text {th }}$ animal with expected value zero and variance $\sigma_{a}{ }^{2}$

$\varepsilon=$ random residual effect with expected value zero and variance $\sigma_{e}{ }^{2}$

When the heritability of $\mathrm{M} \%$ was estimated, slaughter weight was added to the model as a covariate. Breeds were analysed together to ensure there where were enough animals in each test station-batch subclass. Because of computing limitations the pedigree information was limited to three generations, the tested animals included.

\section{Results and discussion}

\section{Accuracy of the function}

The coefficient of determination $\left(\mathrm{R}^{2}\right)$ was 0.998 on average, so the third degree polynomial function fitted in the individual age-weight data very well. Before classification of curves, animals with $\mathrm{R}^{2}$ more than three standard deviations below the average were excluded from the data
(1.5\% of all animals); 8618 animals then remained in the growth curve type data.

\section{Growth curve types}

Six different combinations of polynomial regression coefficients of function 1 appeared with the frequencies given in Table 2. The shapes of the corresponding curves for daily gain are presented in Figure 1. Curve types 1 and 2 resemble the traditional view of growth, according to which daily gain first increases and then, after reaching the inflection point, slowly decreases. The majority of animals, $93.2 \%$, had type 1 or 2 curves (Table 2, Figure 1). For $5.0 \%$ of the animals (curve types 3, 4 and 5) the growth rate slowed in the middle of the test period and then increased again towards the end. In curve type 5 , daily gain increased and in type 6 decreased throughout the test period. The proportion of typical growth curves was higher here than in the studies of Kanis (1988) and Schmidt et al. (1991).

Curve types seemed to differ slightly between sexes. Castrates had a greater number of typical curves than gilts $(95.8$ vs $90.8 \%)$. The sex effect, along with the feeding regime, may explain some of the differences in the proportion of typical growth curves observed between our study and studies of Kanis (1988) and Schmidt et al. (1991). In the study of Kanis (1988) there were

Table 2. Distribution of pigs by different growth curve types defined by coefficient signs from the polynomial of the third degree.

\begin{tabular}{llrr}
\hline $\begin{array}{l}\text { Growth } \\
\text { curve type }\end{array}$ & $\begin{array}{l}\text { Combination } \\
\text { of coefficients }\end{array}$ & $\mathrm{n}$ & $\%$ \\
\hline 1 & +++ & 7736 & 89.8 \\
2 & +++ & 291 & 3.4 \\
3 & +++ & 401 & 4.7 \\
4 & +++ & 26 & 0.3 \\
5 & ++- & 157 & 1.8 \\
6 & ++++ & 7 & 0.1 \\
\hline
\end{tabular}




\section{AGRICULTURAL AND FOOD SCIENCE IN FINLAND}

Sevón-Aimonen, M.-L. et al. Genetic parameters for growth traits in pigs

Table 3. Means, standard deviations (sd), coefficient of variation ( $\mathrm{v} \%)$, minimum and maximum for traits studied.

\begin{tabular}{lrrrrr}
\hline Trait & mean & sd & $\mathrm{v} \%$ & $\min$ & $\max$ \\
\hline $\mathrm{LW}_{\text {ip }}, \mathrm{kg}$ & 71.9 & 8.6 & 12.0 & 27.1 & 103.4 \\
$\mathrm{AGE}_{\mathrm{ip}}, \mathrm{d}$ & 126 & 11.7 & 9.3 & 71 & 176 \\
$\mathrm{DG}_{\max }, \mathrm{g} / \mathrm{pv}$ & 1111 & 121.1 & 10.9 & 712 & 1675 \\
$\mathrm{ADG}_{30-50}, \mathrm{~g} / \mathrm{d}$ & 829 & 81.4 & 9.8 & 493 & 1188 \\
$\mathrm{ADG}_{50-70}, \mathrm{~g} / \mathrm{d}$ & 1042 & 101.0 & 9.7 & 691 & 1479 \\
$\mathrm{ADG}_{70-90}, \mathrm{~g} / \mathrm{d}$ & 1046 & 135.8 & 13.0 & 401 & 1522 \\
$\mathrm{ADG}_{30-90}, \mathrm{~g} / \mathrm{d}$ & 956 & 84.6 & 8.9 & 591 & 1267 \\
$\mathrm{M} \%^{\mathrm{n}=7419}$ & 56.5 & 2.1 & 3.7 & 47.1 & 64.4 \\
\hline
\end{tabular}

1) $\mathrm{LW}_{\mathrm{ip}}=$ live weight at point of inflection in fitted polynomial $\mathrm{AGE}_{\mathrm{ip}}=$ age at point of inflection in fitted polynomial $\mathrm{DG}_{\max }=$ maximum daily gain

$\mathrm{ADG}_{\text {weight1-weight2 }}=$ average daily gain within period of given live weights

$\mathrm{M} \%$ = percentage of lean meat with bone of high value cuts (back, shoulder, loin and ham) in carcass with head

three different data sets: barrows with ad libitum access to feed, gilts with ad libitum access to feed and barrows with restricted feeding. Growth curve types were classified according to a non-linear function (daily gain $=\mathrm{f}$ (weight)) fitted directly to daily gains measured weekly. The percentages of typical growth curves were $83.1,60.6$ and 90.6 , respectively. In the study of Schmidt et al. (1991), all animals were gilts with ad libitum access to feed. Growth curve types were classified as in the present study using signs of the polynomial regression coefficient of function age $=\mathrm{f}$ (weight); $69 \%$ of pigs had a typical growth curve.

\section{Means and variances}

Maximum gain (1111 g/d, on average) was reached when animals weighed $72 \mathrm{~kg}$ and were 126 days old, on average (Table 3, Figure 2). In the literature, estimates of weight at the point of inflection vary from about $60 \mathrm{~kg}$ to over $100 \mathrm{~kg}$ (Schneider 1974, Walstra 1980, Kanis 1988,
Schmidt et al. 1991) depending on breed, sex, feeding scale etc.

The average daily gain increased from 829 $\mathrm{g} / \mathrm{d}$ between 30 and $50 \mathrm{~kg}$ live weight to $1046 \mathrm{~g} / \mathrm{d}$ between 70 and $90 \mathrm{~kg}$ live weight. The average daily gains within the last two weight ranges examined were almost equal. Depending on the properties of the function chosen, the curve for daily gain is a parabola and thus symmetrical around a vertical line through its maximum, which, as mentioned before, was very close to $70 \mathrm{~kg}$ live weight, on average. However, due to the high coefficient of determination the curve probably reflects real growth patterns of pigs during the test period.

\section{Some factors affecting the traits examined}

The effect of sex on $\mathrm{DG}_{\max }, \mathrm{AGE}_{\mathrm{ip}}$, all average daily gains within different weight ranges and M\% was statistically highly significant. There was, however, no difference between sexes in $\mathrm{LW}_{\text {ip }}$. Castrates were three days younger than gilts at the time of $\mathrm{DG}_{\max }$. The average of $\mathrm{DG}_{\max }$ was $112 \mathrm{~g}$ higher in castrates than in gilts (Figure 2) and $\mathrm{ADG}_{30-90}$ was $79 \mathrm{~g}$ better in castrates. The sex difference in daily gain increased towards the end of the test period, being $48 \mathrm{~g} / \mathrm{g}$ from 30 to $50 \mathrm{~kg}, 96 \mathrm{~g} / \mathrm{d}$ from 50 to $70 \mathrm{~kg}$ and $107 \mathrm{~g} / \mathrm{d}$ from 70 to $90 \mathrm{~kg}$. The difference in growth rate was largest around the inflection point, at about $72 \mathrm{~kg}$ live weight. In M\% the sex difference was 1.9 percentage units, in favour of gilts.

The results of sex effects on $\mathrm{LW}_{\text {ip }}$ reported elsewhere are contradictory. In studies of Walstra (1980) and Kanis (1988), maximum gain was reached at a lower body weight in castrates than in gilts. In the study of Schneider (1974), the inflection point was at a lower body weight in gilts than in castrates. The higher growth rate and lower leanness of castrates at feeding levels roughly the sama as those used here has been widely documented (e.g. Richmond and Berg 
Vol. 6 (1997): 1-10.

1971, Cöp and Buiting 1977, Johansson et al. 1987b).

The sex ratio in the test group of fullsibs had no effect on either $\mathrm{LW}_{\mathrm{ip}}$ or $\mathrm{AGE}_{\mathrm{ip}}$. The effect of sex ratio on $\mathrm{DG}_{\max }$ and on average daily gains in all weight ranges examined was, however, statistically highly significant. The smaller the number of castrates in the test group, the better was the average daily gain of both castrates and gilts. In $\mathrm{ADG}_{30-90}$ the difference between the extreme groups (four castrates vs four gilts) was $50 \mathrm{~g} / \mathrm{d}$. In castrates the effect was most marked before $70 \mathrm{~kg}$ live weight and in gilts after $70 \mathrm{~kg}$ live weight. In the test group the sex ratio had no effect on $\mathbf{M} \%$. These results are consistent with those of Ollivier (1977), who suggested that sex ratio within a pen may have an important effect on growth. It has been reported that castrates tend to dominate gilts in restricted feeding systems (Cöp and Buiting 1977, Johansson et al. 1987b).

\section{Heritabilities}

The weight at which the pig reaches its maximum daily gain $\left(\mathrm{LW}_{\mathrm{ip}}\right)$ was determinated only slightly by additive genetic components (Table 4). Heritability for $\mathrm{AGE}_{\mathrm{ip}}$ was moderate, but this was probably due to the marked effect of the herd on age at arrival at the test station and thus also on age at the point of inflection. In the study of Schmidt et al. (1991), heritability estimates for weight and age at the point of inflection were 0.22 and 0.38 , respectively.

Estimates of heritability for the average daily gain at different weight ranges varied from 0.14 to 0.23 . The estimate of heritability for short weight ranges was lowest for $\mathrm{ADG}_{30-50}$ and highest for ADG70-90, possibly because of the diminishing relative magnitude of maternal and herd effects. The estimate of heritability for $\mathrm{ADG}_{30-90}$ was higher than observed in any of the short weight ranges. Thus, a wider weight range enables an animal to compensate for short term environmental fluctuations in growth.
Table 4. Estimates of heritability $\left(\mathrm{h}^{2}\right)$ and permanent environmental effects $\left(c^{2}\right)$.

\begin{tabular}{lcl}
\hline Trait $^{1)}$ & $\mathrm{h}^{2}$ & $\mathrm{c}^{2}$ \\
\hline $\mathrm{LW}_{\text {ip }}$ & 0.08 & 0.08 \\
AGE $_{\text {ip }}$ & 0.33 & 0.17 \\
DG $_{\text {max }}$ & 0.19 & 0.05 \\
ADG $_{30-50}$ & 0.14 & 0.08 \\
ADG $_{50-70}$ & 0.17 & 0.05 \\
ADG $_{70-90}$ & 0.21 & 0.05 \\
ADG $_{30-90}$ & 0.23 & 0.03 \\
$\mathrm{M} \%$ & 0.60 & 0.05 \\
\hline
\end{tabular}

${ }^{1)} \mathrm{LW}_{\text {ip }}=$ live weight at point of inflection in fitted polynomial $\mathrm{AGE}_{\mathrm{ip}}^{\mathrm{ip}}=$ age at point of inflection in fitted polynomial $\mathrm{DG}_{\max }=$ maximum daily gain

$\mathrm{ADG}_{\text {weight1-weight2 }}=$ average daily gain within period of given live weights

$\mathrm{M} \%$ = percentage of lean meat with bone of high value cuts (back, shoulder, loin and ham) in carcass with head

The heritability estimates for daily gain obtained in this study were somewhat lower than the majority of estimates presented by other authors (e.g. McKay and Garnett 1986, Geri et al. 1990, Schmidt et al. 1991), although estimates at a similar level to those found here have also been reported (e.g. Johansson et al. 1987a, Stern et al. 1990, Bryner et al. 1992).

The heritability of M\% (0.60) in our study was in good agreement with the average level of heritabilities of carcass traits reported elsewhere (e.g. Lundeheim et al. 1980, Johansson et al. 1987a, Bereskin and Steele 1988, Stern et al. 1990, Schmidt et al. 1991).

\section{Phenotypic and genetic correlations}

The phenotypic and genetic correlations between $\mathrm{LW}_{\text {ip }}$ and $\mathrm{ADG}_{30-90}$ were positive (Table 5), implying that fast growing animals reach their point of inflection at a later stage than animals growing at a slower rate. This result is the opposite of that obtained by Schmidt et al. (1991). In their study, the genetic correlation between weight at the point of inflection and growth rate (between 


\section{AGRICULTURAL AND FOOD SCIENCE IN FINLAND}

Sevón-Aimonen, M.-L. et al. Genetic parameters for growth traits in pigs

Table 5. Genetic (above diagonal) and phenotypic correlations among traits studied.

\begin{tabular}{lcccccccc}
\hline Trait ${ }^{1)}$ & $\mathrm{LW}_{\text {ip }}$ & $\mathrm{AGE}_{\text {ip }}$ & $\mathrm{DG}_{\max }$ & $\mathrm{ADG}_{30.50}$ & $\mathrm{ADG}_{50-70}$ & $\mathrm{ADG}_{70.90}$ & $\mathrm{ADG}_{30.90}$ & $\mathrm{M} \%$ \\
\hline $\mathrm{LW}_{\text {ip }}$ & & +0.42 & +0.73 & -0.02 & +0.54 & +0.87 & +0.58 & +0.57 \\
$\mathrm{AGE}_{\text {ip }}$ & +0.78 & & +0.20 & -0.37 & -0.02 & +0.23 & -0.04 & +0.46 \\
$\mathrm{DG}_{\max }$ & +0.25 & -0.01 & & +0.54 & +0.97 & +0.98 & +0.94 & +0.19 \\
$\mathrm{ADG}_{30.50}$ & -0.18 & -0.45 & +0.17 & & +0.78 & +0.45 & +0.80 & -0.15 \\
$\mathrm{ADG}_{50.70}$ & -0.09 & -0.30 & +0.88 & +0.44 & & +0.91 & +0.99 & -0.03 \\
$\mathrm{ADG}_{70.90}$ & +0.57 & +0.25 & +0.81 & +0.16 & +0.63 & & +0.93 & +0.27 \\
$\mathrm{ADG}_{30.90}$ & +0.20 & -0.16 & +0.76 & +0.71 & +0.84 & +0.79 & & +0.09 \\
$\mathrm{M} \%$ & +0.11 & +0.22 & -0.12 & -0.30 & -0.24 & -0.09 & -0.16 & \\
\hline
\end{tabular}

${ }^{1)} \mathrm{LW}_{\text {ip }}=$ live weight at point of inflection in fitted polynomial

$\mathrm{AGE}_{\text {ip }}=$ age at point of inflection in fitted polynomial

$\mathrm{DG}_{\max }=$ maximum daily gain

$\mathrm{ADG}_{\text {weight 1-weight } 2}=$ average daily gain within period of given live weights

$\mathrm{M} \%$ = percentage of lean meat with bone of high value cuts (back, shoulder, loin and ham) in carcass with head

30 and $100 \mathrm{~kg}$ ) was negative $(-0.30)$. In growth curve studies on laboratory animals (Timon and Eisen 1970, Aumann and Butler-Wemken 1992), however, the results have been in agreement with those obtained here.

The correlation between $\mathrm{LW}_{\text {ip }}$ and $\mathrm{M} \%$ was phenotypically slightly and genetically clearly positive (Table 5). Thus, animals increasing their growth rate up to a high live weight were also lean. In the study of Schmidt et al. (1991) the corresponding genetic correlation was negative $(-0.28)$.

The genetic correlations among average daily gains in different weight ranges were fairly high, indicating that mainly the same genetic factors regulate growth throughout the growing period. However, the correlations were not close to unity, and thus some genetic differences in growth patterns may exist. The correlation between $\mathrm{ADG}_{30-50}$ and $\mathrm{ADG}_{50-70}$ was lower than the correlation between $\mathrm{ADG}_{50-70}$ and $\mathrm{ADG}_{70-90^{\circ}}$ One explanation for this might be that growth rate is affected by other genetic factors besides those directly regulating growth, especially in the first weight range. For example, animals with stress susceptibility might, as a consequence of changes in their environment, feed etc., grow slowly at the beginning of the test, even if they have good genetic potential for growth. On the other hand, as mentioned before, the symmetry of the daily gain curve hampers interpretation of the results somewhat. Many researchers have concluded that in general, growth is mainly regulated by the same genetic factors at all stages (Fredeen and Mikami 1986, Johansson et al. 1987a, Rydhmer et al. 1989).

The phenotypic correlations between average daily gain and $\mathrm{M} \%$ were negative (Table 5), i.e. fast growing animals had a higher percentage of fat than slow growing animals. The negative correlation was largest between $\mathrm{ADG}_{30-50}$ and M\%. The genetic correlation between average daily gain in the first weight range and $\mathrm{M} \%$ was also clearly negative. The genetic correlation between $\mathrm{ADG}_{50-70}$ and $\mathrm{M} \%$ was close to zero and between $\mathrm{ADG}_{70-90}$ and $\mathrm{M} \%$ clearly positive. The results are somewhat contradictory, since growth in at the beginning of the growing period has usually been attributed to growth of muscles and at the end of the growing period increasingly to growth of fat tissue. The phenomenon we observed may be associated with the protein content of the feed and the feeding scale used. The amount of lysine in feed was obviously a restrictive factor in lean growth for the best animals at the beginning of test period. In general, the results indicated that there is no significant antagonistic relationship between $\mathrm{M} \%$ and the aver- 
Vol. 6 (1997): 1-10.

age daily gain during the whole growing period. In the literature, the results of correlations between growth and leanness vary. With ad libitum feeding, correlations tend to be unfavourable (e.g. Kennedy et al. 1985, Schmidt et al. 1991). With restricted feeding, however, the correlations can be close to zero (e.g. Bryner et al. 1992) or even positive (e.g. Johansson et al. 1987b).

\section{Conclusions}

Most animals had a typical growth curve with an inflection point at about $72 \mathrm{~kg}$ live weight.
Growth rate seemed to be clearly affected by the ratio of sexes in the test group. More research would be needed to clarify the importance of the effect of the sex ratio on testing results.

The feeding system may have been the main reason for the limited genetic variation in the growth pattern. The relatively high genetic correlations between average daily gain at different weight ranges indicated that growth at all stages is regulated mainly, but not entirely, by the same genetic effects. However, the measures of daily gains at different weight ranges were obtained from the same fitted polynomial, and hence were not independent measures. No major antagonistic relationship between growth rate and leanness was observed.

\section{References}

Aumann, J. \& Butler-Wemken, I. von. 1992. Einfluss antagonistischer Körpergewichtsselection und Kreuzung auf den Wachstumsverlauf einer Măusepopulation. Archiv für Tierzucht 35: 201-210.

Bereskin, B. \& Steele, N.C. 1988. Estimates of genetic parameters for carcass measures of body composition and growth in swine. Journal of Animal Science 66: 2498-2507.

Brody, S. 1945. Bioenergetics and growth. New York, Reinhold Publication corporation. 1023 p. (ref. Walstra 1980).

Bryner, S.M., Mabry, J.W., Bertrand, J.K., Benyshek, L.L., Cöp, W.A.G. \& Buiting, G.A.J. 1977. Feed intake in six lines of pigs and its influence on growth and carcass traits. Animal Production 25: 291-304.

Fitzhugh, H.A. Jr. 1976. Analysis of growth curves and strategies for altering their shape. Journal of Animal Science 42: 1036-1051.

Fredeen, H.T. \& Mikami, H. 1986. Mass selection in a pig population: correlated responses in preweaning growth. Journal of Animal Science 62: 1533-1545.

Geri, G., Franci, O., Zappa, A., Campodoni, G. \& Poli, B.M. 1990. Relationships between adipose tissue characteristics of newborn pigs and subsequent performance: I. Characteristics at 8 days of age and growth rate until slaughter. Journal of Animal Science 68: 1922-1928.

Groeneveld, E. 1990. PEST user's manual. Institute of Animal husbandry and Animal Behaviour, Federal Agricultural Research Centre, Germany. 73 p.

- 1993. A multivariate multimodel REML package. Preliminary user's guide. Institute of Animal Husbandry and Animal Behaviour, Federal Agricultural Research Centre, Germany. 9 p.

Johansson, K., Andersson, K. \& Lundeheim, N. 1987a. Evaluation of station testing of pigs. I. Genetic parameters for feed measurements and selection effects on voluntary feed intake. Acta Agriculturea Scandinavica 37: 93-107.

-, Andersson, K. \& Sigvardsson, J. 1987b. Evaluation of station testing of pigs. III. The genetic parameters for carcass measurements of partially dissected pigs. Acta Agriculturae Scandinavica 37: 120-129.

Kanis, E. 1988. Food intake capacity in relation to breeding and feeding of growing pigs. Wageningen Agricultural University, The Netherlands. 129 p. Doctoral thesis.

Kennedy, B.W., Johansson, K. \& Hudson, G.F.S. 1985. Heritabilities and genetic correlation for backfat and age at $90 \mathrm{~kg}$ in performance-tested pigs. Journal of Animal Science 61: 78-82.

Koops, W.J. \& Grossmann, M. 1991. Applications of a multiphasic growth function to body composition of pigs. Journal of Animal Science 69: 3265-3273.

Laird, A.K. 1966. Postnatal growth of birds and mammals. Growth 30: 349. (Ref. Fitzhugh 1976).

Lundeheim, N., Johansson, K. \& Andersson, K. 1980. Estimated phenotypic and genetic parameters based on data from the Swedish pig progeny testing stations. Acta Agriculturae Scandinavica 30: 183-188.

McKay, R.M. \& Garnett, I. 1986. Prenatal and postnatal influences on growth and fat measurements in swine. Journal of Animal Science 63: 1095-1100.

Ollivier, L. 1977. Note: Effet défavorable du mélage des 


\title{
AGRICULTURAL AND FOOD SCIENCE IN FINLAND
}

Sevón-Aimonen, M.-L. et al. Genetic parameters for growth traits in pigs

sexes dans l'engraissement des porcs en groupe. Annales de Zootechnique 26: 615-619.

Patterson, H.D. \& Thompson, R. 1971. Recovery of interblock information when block sizes are unequal. Biometrika 58: 427-436.

Richards, J.F. 1959. A flexible growth function for empirical use. Journal of Experimental Botanic 10: 290. (Ref. Fitzhugh 1976).

Richmond, R.J. \& Berg, R.T. 1971. Tissue developement in swine as influenced by liveweight, breed, sex and ration. Canadian Journal of Animal Science 51: 3139.

Rydhmer, L., Eliasson, L., Stern, K., Andersson, K. \& Einarsson, S. 1989. Effects of piglet weight and fraternity size on performance, puberty and farrowing results. Acta Agriculturae Scandinavica 39: 397-406.

Salo, M.-L., Tuori, M. \& Kiiskinen, T. 1990. Rehutaulukot ja ruokintanormit. 70 p. Yliopistopaino,Helsinki. (In Finnish: Feed tables and feeding allowances).

Schmidt, E. von., Krieter, J. \& Kalm, E. 1991. Wachstum beim Schwein: Vergleich von Funktionen sowie Verlauf von Tageszunahme und Futteraufnahme und deren Beziehung zum Schlachtkőperwert. Züchtungskunde 63: 306-316.

Schneider, A. 1974. Die Zühterichen Möglichkeiten unter ad libitum Fütterung beim Schwein. Eidgenös- sichen Technischen Hochschule. Zürich. 93 p. Doctoral thesis.

Stern, S., Rydhmer, L., Johansson, K. \& Andersson, K. 1990. Selection for lean tissue growth rate in Swedish Yorkshire pigs on low or high protein diets. Proceedings of the 4th World Congress on Genetics applied to Livestock Production. Edingburgh, UK. XV: 450-453.

Timon, V.M. \& Eisen, E.J. 1970. Comparisons of restricted feeding of mice selected and unselected for postweaning gain. 1. Growth, feed consumption and feed efficiency. Genetics 64:41.

Vangen, O. 1977. Studies on a two trait selection experiment in pigs. I. Growth, feed consumption and feed conversion ratio after 10 years of selection for growth rate and backfat thickness. Acta Agriculturae Scandinavica 27: 331-340.

Walstra, P. 1980. Growth and carcass composition from birth to maturity in relation to feeding level and sex in Dutch Landrace pigs. Mededelingen Landbouwhogesscool Wageningen. The Netherlands. 206 p. Doctoral Thesis.

Whittemore, C.T. 1986. An approach to pig growth modelling. Journal of Animal Science 63: 615-621.

- 1987. Elements of pig science. Harlow, Essex Longman Scientific \& Technical. $181 \mathrm{p}$.

\section{SELOSTUS}

\section{Sian kasvuominaisuuksien perinnölliset tunnusluvut arvioituna kolmannen asteen polynomifunktion avulla}

\author{
Marja-Liisa Sevón-Aimonen, Kristina Sternberg ja Matti Ojala \\ Helsingin yliopisto
}

Tutkimuksessa selvitettiin joidenkin sian kasvua kuvaavien muuttujien periytyvyyttä. Suomen kotieläinjalostusosuuskunnan kantakoeaineistosta poimittiin yhteensä 8745 yorkshire- ja maatiaisrotuisen sian tiedot. Kokeen aikana eläimet oli punnittu viikoittain. Jokaisen sian punnitustietoihin sovitettiin kolmannen asteen polynomifuntio $i k a ̈=f(p a i n o)$, jota käytettiin kuvaamaan yksittäisen sian kasvurytmiä ja kasvunopeutta. Kasvuominaisuuksien ja ruhon laadun periytymisasteet ja ominaisuuksien väliset korrelaatiot estimoitiin käyttäen REMLiä ja eläinmallia.

Sovitetun polynomifunktion selitysaste $\left(\mathrm{R}^{2}\right)$ oli $98,5 \%$ :lla sioista yli 0,99 . Sikojen paino funktion käännepisteessä eli maksimikasvun kohdalla oli keskimäärin $72 \mathrm{~kg}$, ikä 126 vrk ja päiväkasvu $1111 \mathrm{~g} / \mathrm{vrk}$.
Keskimääräinen päiväkasvu painovälillä $30-90 \mathrm{~kg}$ oli $957 \mathrm{~g} / \mathrm{vrk}$. Lyhyillä painoväleillä $30-50 \mathrm{~kg}, 50-$ 70 kg ja 70-90 kg keskimääräiset päiväkasvut olivat vastaavasti $829 \mathrm{~g} / \mathrm{vrk}, 1042 \mathrm{~g} / \mathrm{vrk}$ ja $1046 \mathrm{~g} / \mathrm{vrk}$. Käännepisteen elopainon periytymisastearvio oli 0,08 ja kasvuominaisuuksien periytymisastearviot vaihtelivat alkukasvun 0,14:stä koko jakson 0,23:een.

Geneettiset korrelaatiot eri painovälien keskimääräisten kasvujen välillä olivat $0,45-0,95$. Nopeakasvuisten ja lihakkaiden eläinten kasvu hidastui suuremmassa elopainossa kuin hidaskasvuisten eläinten. Ruhon laadun ja kasvunopeuden välillä ei ollut epäsuotuista geneettistä yhteyttä. Vähäinen perinnöllinen vaihtelu funktion käännepisteen sijainnissa saattaa johtua noudatetusta rajoitetusta ruokintanormista. 